Interrupted Life 


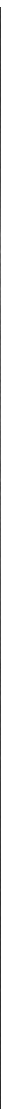

(c) Paula C. Johnson 


\section{Interrupted Life}

Experiences of Incarcerated Women in the United States

Edited by

Rickie Solinger, Paula C. Johnson, Martha L. Raimon, Tina Reynolds, and Ruby C. Tapia

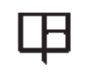

UNIVERSITY OF CALIFORNIA PRESS

Berkeley Los Angeles London 
University of California Press, one of the most distinguished university presses in the United States, enriches lives around the world by advancing scholarship in the humanities, social sciences, and natural sciences. Its activities are supported by the UC Press Foundation and by philanthropic contributions from individuals and institutions. For more information, visit www.ucpress.edu.

University of California Press

Berkeley and Los Angeles, California

University of California Press, Ltd.

London, England

(C) 2010 by The Regents of the University of California

Library of Congress Cataloging-in-Publication Data

Interrupted life : experiences of incarcerated women in the United States / edited by Rickie Solinger ... [et al.].

p. $\mathrm{cm}$.

Includes bibliographical references and index.

ISBN 978-0-520-25249-3 (cloth : alk. paper)-ISBN 978-0-520-25889-1 (pbk. : alk. paper)

1. Women prisoners-United States. 2. Female offenders-United

States. 3. Women prisoners-Abuse of-United States. 4. Children of women prisoners-Services for-United States. 5. Women prisonersFamily relationships-United States. I. Solinger, Rickie, 1947-

HV9471.I63 2010

$365^{\prime} \cdot 430973-\mathrm{dc} 22$

2009023612

Manufactured in the United States of America

$\begin{array}{llllllllll}19 & 18 & 17 & 16 & 15 & 14 & 13 & 12 & 11 & 10\end{array}$

$\begin{array}{llllllllll}10 & 9 & 8 & 7 & 6 & 5 & 4 & 3 & 2 & 1\end{array}$

Every effort has been made to identify the rightful copyright holders of material not specifically commissioned for use in this publication and to secure permission, where applicable, for reuse of all such material. Credit, if and as available, has been provided for all borrowed material either onpage, on the copyright page, or in an acknowledgment section of the book. Errors or omissions in credit citations or failure to obtain permission if required by copyright law have been either unavoidable or unintentional. The author and publisher welcome any information that would allow them to correct future reprints.

This book is printed on Cascades Enviro 100, a 100\% post consumer waste, recycled, de-inked fiber. FSC recycled certified and processed chlorine free. It is acid free, Ecologo certified, and manufactured by BioGas energy. 